\title{
Molecular Investigation of Rifampicin Resistance in Clinical Isolates of Mycobacterium ulcerans in Côte D'ivoire
}

\author{
Bakary Coulibaly ${ }^{1 *}$, David N'golo Coulibaly², Clément Kouassi Kouassi ${ }^{1}$, \\ Ibrahim Konaté ${ }^{1}$, Elise Solange Ngazoa-Kakou ${ }^{2}$ and Mireille Dosso ${ }^{2}$
}
${ }^{1}$ UFR Agroforestry, Agrovalorization Laboratory, Department of Biochemistry Microbiology, Jean Lorougnon Guédé University, BP 150 Daloa, Ivory Coast
${ }^{2}$ Molecular Biology Platform, Institut Pasteur Côte d'Ivoire, BP 490 Abidjan, Ivory Coast

*Corresponding author:

\section{A B S T R A C T}

\begin{abstract}
Keywords
M. ulcerans, PCR, IS2404, Buruli ulcer, Ivory Coast, $R p o B$ gene, ISKR sequence this mycobacterium is based on microbiological analyzes, including PCR, which uses the nucleotide sequences of the primers to detect the targeted sequences. Cases of rifampicin resistance were recorded in mice experimentally infected with $M$. ulcerans strains and treated with rifampicin in previous studies. In this study, clinical isolates were confirmed as $M$. ulcerans strains. These isolates are from samples of patients with Buruli ulcer. The PCR gave a positivity rate of $92.10 \%$ for the detection of the IS 2404 sequence and made it possible to highlight the virulence gene in most of the strains studied with a positivity rate

Article Info

Accepted:

10 March 2019

Available Online:

10 April 2019 of $94.74 \%$ for the detection of the sequence IS-KR. However, the RpoB gene could not be found in any of the strains. Thus it gives a positivity rate of $0 \%$ for the detection of this gene. The results show that most strains of $M$. ulcerans secrete mycolactone. The production of this toxin is the consequence of a mutation in the IS-KR gene. They also show that rifampicin has an effective bactericidal activity against $M$. ulcerans strains and that resistance to this antibiotic results from a mutation of the $R p o B$ gene.
\end{abstract}

M. ulcerans is the etiologic agent of Buruli ulcer. The clinical diagnosis of infection with

\section{Introduction}

The advent of antibiotic therapy in the 1940s completely revolutionized the medical field and resulted in a significant reduction in mortality associated with infectious diseases (Conly, 2002). But the bacterial world has adapted to antibiotics and this has resulted in the emergence of resistant strains in humans, animals and the environment. The existence of these resistant bacteria has consequences on therapeutics, public health and environmental hygiene (Guillot, 1989). Bacterial resistance to traditional antibiotics has rapidly become a global health problem (Conly, 2002). M. ulcerans is a Mycobacterium of the same family as that responsible for tuberculosis and leprosy. It causes extensive and disabling chronic skin ulcerations commonly referred to as Buruli Ulcer (Coulibaly et al., 2011). It is the only mycobacterium known to date that produces a 
toxin (mycolactone) responsible for the pathogenicity of bacilli (Asiedu et al., 2000). The current drug treatment is based on the use of the combination of rifampicin and streptomycin (Etuaful et al., 2005) almost always without prior antibiogram. However, one study revealed the risk of the emergence of resistance of some strains of $M$. ulcerans in an experimentally infected mouse treated only with rifampicin (Marsollier et al., 2003).

A better understanding of the modes of action of different antibiotics will allow to consider the genotypic detection of most resistances. Thus, the detection of major mutations in the main genes could be an effective and rapid demonstration of antibiotic resistance, even if this means has until now been applied only for resistance to rifampicin (Cattoir, 2004 ).

This study makes it possible to evaluate the resistance to antimycobacterial agents and more particularly to Rifampicin by different approaches. It will identify ways to overcome the problem of antimycobacterial resistance through the elucidation of resistance mechanisms and the detection of resistance cases.

\section{Materials and Methods}

\section{Study site}

The present study was carried out at the Institut Pasteur of Ivory Coast, located in ADIOPODOUME (Km 17, road of Dabou) (Fig. 1).

\section{Biological material}

The biological material consists of 76 bacterial strains obtained from biological samples (exudates and biopsies) of patients with Buruli ulcer in Ivory Coast. The bacterial strains were obtained after culture on Löwenstein-Jensen medium and stored in glycerol at $-20^{\circ} \mathrm{C}$.

\section{Methods}

\section{Detection of specific sequences (IS2404, IS $\mathrm{KR}, \mathrm{rpoB})$}

\section{Extraction of genomic DNA}

The extraction of the genomic DNA was carried out by thermal shock. The technique consisted of distributing a bacterial suspension in Eppendorf tubes due to $200 \mu \mathrm{l} /$ tube. The tubes are centrifuged at 15,000 rpm at $4{ }^{\circ} \mathrm{C}$. for 15 minutes and the pellet of each tube is suspended in $100 \mu \mathrm{l}$ of $50 \mathrm{mM} \mathrm{NaOH}$. The tubes are then heated at $95^{\circ} \mathrm{C}$. for 15 minutes and then a volume of $15 \mu \mathrm{l}$ of $0.1 \mathrm{M}$ Tris- $\mathrm{HCl}$ is added to the bacterial suspension to neutralize the $\mathrm{pH}$ of the medium. The bacterial cells burst to release the DNA which is recovered by centrifugation. The liberated DNA is precipitated with 20.Mu.1 (3M sodium acetate) and 500.Mu.l of absolute ethanol stored at -20.degree. The tubes are incubated at $-20^{\circ} \mathrm{C}$ overnight and then centrifuged at $13000 \mathrm{rpm}$ at $4^{\circ} \mathrm{C}$ for 20 minutes. The supernatant is removed and the bacterial pellets are washed in a volume of 1 $\mathrm{ml}$ of $70 \%$ ethanol previously stored at $-20^{\circ}$ C. The tubes are centrifuged again at 13000 rpm at $4{ }^{\circ} \mathrm{C}$ for 5 minutes and the supernatant is removed. The pellets are dried at $50^{\circ} \mathrm{C}$. for $20 \mathrm{~min}$ and then recovered in $100 \mu \mathrm{l}$ of elution buffer TE $(\mathrm{pH}=8)$ containing RNAse at $20 \mu \mathrm{g} / \mathrm{ml}$.

\section{Gene amplification}

\section{Reaction mixture for detecting IS2404 sequence and amplification}

The amplification reactions targeting the insertion sequence IS2404 and generating 568 bp PCR products were carried out in a final reaction volume of $20 \mu \mathrm{l}$ containing $12 \mu \mathrm{l}$ of sterile distilled water; $2.5 \mu \mathrm{l}$ of buffer $(5 \mathrm{X})$; $1.3 \mu \mathrm{l}$ of $\mathrm{MgCl} 2(25 \mu \mathrm{M}) ; 0.5 \mu \mathrm{l}$ of each deoxynucleotide triphosphate $(10 \mu \mathrm{M}$ 
dNTPs); $0.75 \mu$ of each primer (Mu-R / MuF) and $0.2 \mu \mathrm{l}$ of the Taq polymerase. Positive and negative controls are included at each test to check for possible contamination of reagents or samples. The gene amplification is carried out in a thermocycler of GeneAmp 9700 type (Applied Biosystem) under the conditions mentioned below: It starts with an initial denaturation of $2 \mathrm{~min}$ at $50^{\circ} \mathrm{C}$., followed by a cyclic step repeated 40 times, comprising a denaturation phase of $10 \mathrm{~min}$ at $95^{\circ} \mathrm{C}$, a primer fixation phase of $15 \mathrm{sec}$ at 95 ${ }^{\circ} \mathrm{C}$ and an elongation phase of $1 \mathrm{~min}$ at $60^{\circ}$ C. At the end of the cyclic phase, a final elongation of 5 minutes is carried out at $72^{\circ}$ C.

\section{Reaction mixture for detecting IS-KR sequence and amplification}

Detection of the IS $\mathrm{Kr}$ insertion sequence and generating $330 \mathrm{pb}$ PCR products, were carried out in a final reaction volume of $20 \mu \mathrm{l}$ containing $12 \mu \mathrm{l}$ of sterile distilled water; 2.5 $\mu \mathrm{l}$ of buffer $(5 \mathrm{X}) ; 1.3 \mu \mathrm{l}$ of $\mathrm{MgCl}_{2}(25 \mu \mathrm{M})$; $0.5 \mu$ of each deoxynucleotide triphosphate (10 $\mu \mathrm{M}$ dNTPs); $0.75 \mu \mathrm{l}$ of each primer (Mu$\mathrm{R} / \mathrm{Mu}-\mathrm{F}$ ) and $0.2 \mu \mathrm{l}$ of the Taq polymerase. Positive and negative controls are included in each trial. The gene amplification is carried out in a thermal cycler of GeneAmp 9700 type (AppliedBiosystem) under the following conditions: It begins with an initial denaturation of $2 \mathrm{~min}$ at $50^{\circ} \mathrm{C}$, followed by a cyclic step repeated 40 times, comprising a phase denaturation time of $10 \mathrm{~min}$ at $95^{\circ} \mathrm{C}$., a primer fixation phase of $15 \mathrm{sec}$ at $95^{\circ} \mathrm{C}$. and an elongation phase of $1 \mathrm{~min}$ at $60^{\circ} \mathrm{C}$. At the end of the cyclic phase, a final elongation of 5 minutes is carried out at $72^{\circ} \mathrm{C}$.

\section{Rifampicin Resistance (RpoB) Gene Detection Mixture and Amplification}

The amplification reactions targeting the rpoB gene sequence and generating 606bp PCR products were carried out in a final reaction volume of 20.mu.l containing 12.mu.l of sterile distilled water; $2.5 \mu \mathrm{l}$ of buffer (5X); $1.2 \mu \mathrm{l}$ of $\mathrm{MgCl} 2(25 \mu \mathrm{M}) ; 1.6 \mu \mathrm{l}$ of each deoxynucleotide triphosphate $(10 \mu \mathrm{M}$ dNTPs); $0.3 \mu \mathrm{l}$ of each primer (MuB-R / MuB-F) and $0.2 \mu l$ of Taq polymerase. Positive and negative controls are included at each test to check for possible contamination of reagents or samples.

The amplification is carried out in a thermocycler of GeneAmp 9700 type (AppliedBiosystem) under the conditions mentioned below: it starts with an initial denaturation of $2 \mathrm{~min}$ at $95^{\circ} \mathrm{C}$., followed by a cyclic step repeated 40 times, comprising a phase denature of $20 \mathrm{sec}$ at $95^{\circ} \mathrm{C}$, a primer attachment phase of $10 \mathrm{sec}$ at $63^{\circ} \mathrm{C}$ and an elongation phase of $15 \mathrm{sec}$ at $70^{\circ} \mathrm{C}$. At the end of the cyclic phase, a final elongation of 7 minutes is carried out at $72{ }^{\circ} \mathrm{C}$.

\section{Revelation of amplification products by agarose gel electrophoresis}

The amplified products are revealed after electrophoresis in $1.5 \%$ agarose gel containing SyberSafe DNA gel incorporated during the preparation of the gel, thus allowing visualization of the DNA under UV radiation. Electrophoresis was performed in TAE buffer (Tris Acetate EDTA, 90mM Tris, $90 \mathrm{mM}$ acetic acid, $2 \mathrm{mM}$ EDTA, $\mathrm{pH}$ 8.0). Thus, on a strip of parafilm paper, the different samples to be analyzed are labeled with a mixture of $4 \mu \mathrm{l}$ of loading buffer (bromophenol blue) and $10 \mu \mathrm{l}$ of genetic material. The labeled samples are deposited in wells migration gel, which gel bathes in a migration vessel containing a buffer solution TAE (1x). The migration vessel is energized at 135 volts for about 30 minutes. During migration, a molecular weight marker is used to verify that the resulting bands match the expected size. The gel is then placed in an automated gel reader: the GelDoc imaged where a software allows to photograph under 
Ultra-Violet light $(312 \mathrm{~nm})$ using a photo system.

The gel is then placed in an automated gel reader: the imaged GelDoc where a photo software can photograph under ultra-violet light $(312 \mathrm{~nm})$ using a photo system. A result was considered positive, if the electrophoresis showed the presence of the specific sequence sought (band indicating the number of base pairs).

\section{Results and Discussion}

\section{Detection of the IS2404 insertion sequence}

Detection of the IS2404 insertion sequence from suspect $M$. ulcerans colonies confirmed the presence of this $M$. ulcerans-specific DNA sequence in 70 strains of the 76 suspect strains (Table 1).

Detection of the virulence gene $\mathrm{KR}$ in $M$. ulcerans

The confirmation of the presence of $M$. ulcerans in these microbial strains required complementary molecular analyzes such as the detection by PCR of a ketoreductase sequence present at the $\mathrm{Kr}$ genes encoding the polyketide synthetases. The IS-KR sequence was found in 72 out of 76 strains, a detection rate of $94.74 \%$ (Table 2).

\section{Research of the rifampicin resistance gene (rpoB) at M.ulcerans}

PCR also identified mutations in the $r p o B$ gene conferring resistance to rifampicin. Thus, the detection of the $r p o B$ gene was negative for all the strains studied. This study shows a positivity rate for the detection of resistant mutants of $0 \%$ (Table 3). The analysis of the results shows that of the seventy-six (76) suspicious strains of $M$. ulcerans, six (6) strains were not confirmed as
M. ulcerans strains. In contrast, 70 strains were (Table 1). PCR has therefore confirmed the etiological diagnosis of the agent responsible for skin ulcers. Detection of the KR gene was negative in four (4) of the 76 strains and positive for 72 strains (Table 2). Demonstration of the IS-Kr sequence in isolated strains confirmed the production of mycolactone in these patients. Mycolactone is the only virulence factor identified in $M$. ulcerans. Due to its cytotoxic and immunosuppressive effects, this mycolactone is thought to be responsible for tissue necrosis (Stinear et al.,, 2004). These findings open new avenues for researching pharmaceutical agents targeting polyketide synthetase (Gomez et al., 2004). This study also reveals not only that some mycobacteria other than $M$. ulcerans can cause ulcerations in patients but also other mycobacteria can grow in our culture conditions; hence the need for confirmation from bacterial colonies (Coulibaly et al., 2010). No mutation in the resistance gene could be detected during this study (Table 3). According to this study, rifampicin remains active against $M$. ulcerans strains. The bactericidal action of rifampicin occurs both on intracellularly propagated bacteria and those with low metabolic activity (Campbell et al., 2001). M.ulcerans is susceptible to many antibiotics in vitro. However, in vivo, given the nature of the lesions, antibiotics penetrate with difficulty into poorly vascularized, necrotic tissue. Because of the difficulties of diffusion of antibiotics within the lesions, the studies are moving towards combinations of antibiotics (Portaels et al., 1998). But when used as monotherapy for the treatment of Buruli ulcer, some strains may become resistant to this antibiotic (Marsollier et al., 2003).

The work of Marsollier et al., showed that of 897 strains of $M$. ulcerans inoculated with mice and then treated with rifampicin only, three strains developed mechanisms of 
resistance to this antibiotic. These studies also revealed mutations in the $r p o B$ gene in $M$. ulcerans. These mutations have been identified in the codons corresponding to amino acids 416 and 420. They respectively cause the change of Serine (416) to Phenylalanine and Histidine (420) to Tyrosine. The results of their work indicate that rifampicin is effective against $M$. ulcerans in vitro, but should not be used as monotherapy in humans. The combination of rifampicin / streptomycin antibiotics has been shown to be effective in mice experimentally infected with $M$. ulcerans and allowed for a pilot study in an endemic area in Ghana. Both antibiotics have a bactericidal action. But only their combination protects against relapse and selection of resistant strains (Dega et al., 2000). This antibiotherapy has major interests such as outpatient treatment for many patients and lower cases of relapse after antibiotic treatment. This represents less than $2 \%$ against 16 to $30 \%$ after surgical treatment.

Table.1 Positivity rate of detection of IS 2404 insertion sequence in suspicious strains of $M$. ulcerans

\begin{tabular}{|l|l|l|l|l|}
\hline \multirow{2}{*}{$\begin{array}{l}\text { Effective } \\
\text { some samples }\end{array}$} & \multicolumn{2}{|c|}{ PCR } & SEQUENCE IS 2404 \\
\cline { 2 - 5 } & Negative & Positive & Negative & Positive \\
\hline $\mathrm{N}=76$ & 00 & 76 & 06 & 70 \\
\hline Rate positivity (\%) & 00 & 100 & 7,89 & $\mathbf{9 2 , 1 0}$ \\
\hline
\end{tabular}

$\mathrm{N}$ : Total number of microbial strains

Table.2 Positivity rate of the detection of the virulence gene (KR) in M. ulcerans

\begin{tabular}{|l|l|l|l|l|}
\hline \multirow{2}{*}{$\begin{array}{l}\text { Effective } \\
\text { some samples }\end{array}$} & \multicolumn{2}{|c|}{ PCR } & \multicolumn{2}{c|}{ KR GENE } \\
\cline { 2 - 5 } & Negative & Positive & Negative & Positive \\
\hline N=76 & 00 & 76 & 04 & 72 \\
\hline Rate positivity (\%) & 00 & 100 & 5,26 & $\mathbf{9 4 , 7 4}$ \\
\hline
\end{tabular}

$\mathrm{N}$ : Total number of microbial strains

Table.3 Positivity rate of detection of the resistance gene $(r p o B)$ in $M$. ulcerans

\begin{tabular}{|l|l|l|l|l|}
\hline \multirow{2}{*}{$\begin{array}{l}\text { Effective } \\
\text { some samples }\end{array}$} & \multicolumn{2}{|c|}{ PCR } & \multicolumn{2}{c|}{ rpoB GENE } \\
\cline { 2 - 5 } & Negative & Positive & Negative & Positive \\
\hline $\mathrm{N}=76$ & 00 & 76 & 76 & 00 \\
\hline Rate positivity (\%) & 00 & 100 & 100 & $\mathbf{0 0}$ \\
\hline
\end{tabular}

N: Total number of microbial strains

Fig.1 Location of the Pasteur Institute of Côte d'Ivoire Adiopodoumé site (data obtained by Google Map)

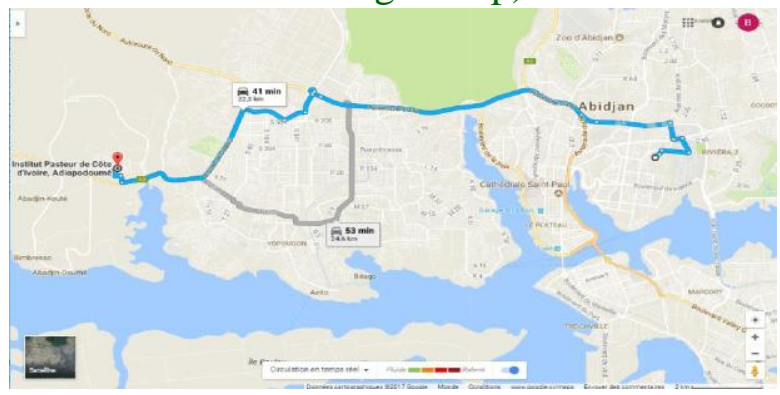


WHO is currently recommending a combination of rifampicin and streptomycin for the treatment of Buruli ulcer and nodules and uncomplicated cases can now be treated as ambulatory (Etuaful et al., 2005). The identification of rifampicin resistance is activated by mutations of the $r p o \beta$ gene. Resistance to rifampicin arises from mutations altering the residues of the rifampicin binding site to RNA polymerase, which results in a decreased affinity for rifampicin. Most of these resistant mutations are located on the rро $\beta$ gene of the RNA polymerase encoding the $\beta$ subunit. (Feklistov et al., 2008). The acquired resistance of $M$. ulcerans to antibiotics is caused by a selection of resistant mutants during inadequate treatment: This is called secondary resistance (Campbell et al., 2001). This selection takes place when a bacillary population is important and a single antibiotic is active. Also when the patient receives a monotherapy in principle (it takes only one of the prescribed antibiotics or the doctor prescribes only one antibiotic) or monotherapy de facto (the bacilli are resistant to other antibiotics prescribed simultaneously).

Buruli ulcer is an infectious disease of chronic evolution. Some aspects of its physiopathology remain unknown. Clinicians as well as researchers are striving to find an alternative to surgical treatment using effective antibiotics on $M$. ulcerans. The methods used to confirm the clinical diagnosis of Buruli ulcer are based on various microbiological analyzes, including the PCR technique. This technique uses nucleotide sequences of the primers to detect the insertion sequence IS2404 and the sequence of ketoreductase present at the genes encoding the polyketide synthetases of plasmid pMUM001. It is also used to detect mutations in the $R p o B$ gene that confer resistance to rifampicin. This study found a large number of microbial strains positive for
IS2404 and KR gene but negative for the $R p o B$ gene. These results show that the mycolactone produced can be detected in human tissues infected with $M$. ulcerans. Also, the absence of a mutation in the $R p o B$ gene makes it possible to show that rifampicin has an effective bactericidal activity on $M$. ulcerans strains. But the knowledge of the reasons (susceptibility factors) of the bacillus establishment in the cutaneous tissue must be identified.

\section{References}

Asiedu K., Sherpbier R., Raviglione MC. 2000. Buruli ulcer Mycobacterium ulcerans infection. W.H.O. Global Buruli ulcer initiative.Report 2000 World Health Organization Geneva, Switzerland. 89 p.

Campbell EA, Korzheva N, Mustaev A. 2001. Structural mechanic for rifampicin inhibition of bacterial RNA polymerase.104:901-12.

Cattoir V. 2004. Efflux-mediated antibiotics resistance in bacteria. Pathol Biol (Paris). 52 (10): 607-16.

Conly J. 2002. Antimicrobial resistance in Canada. CMAJ. 167: 885-91.

Coulibaly Bakary., N'Guessan Kouassi Raymond., Aka N'guetta., Ekaza Euloge., N'golo David Coulibaly., Trébissou Nöel., Ouattara Lassiné., Bahi Calixte., Coulibaly Adama., Assandé Jean Marc., Mohui Philomène., Yao Hubert., Djaman Allico Joseph and DOSSO Mireille. 2011. Activité antimycobactérienne in vitro des extraits de Phyllanthus amarus (Schum et Thonn) sur les souches de Mycobacterium ulcerans en Côte d'Ivoire. Bull Soc Royale Sci Liège. 80: 759 - 771

Coulibaly, B., M.-D.G. Coulibaly-N'Golo., E. Ekaza., N. Aka., K.R. N'Guessan., A. Baudryard., J-M. Assandé., N. Trébissou., F. Guédé-Guina and $\mathrm{M}$. 
Dosso. 2010. Mise en place de la culture in vitro de Mycobacterium ulcerans à partir d'échantillons cliniques versus recherche de BAAR et détection du génome bactérien à Abidjan, Côte d'Ivoire. Bull. Soc. Pathol. Exot. 103: 2-7

Dega H., Robert J., Bonnafous P., Jarlier V \& Grosset J. 2000. Activities of several antimicrobials against Mycobacterium ulcerans infection in mice. Ant $A g$ Chem.44: 2367-2372.

Etuaful S, Carbonnelle B, Grosset J, Lucas S, Horsfield C, Phillips R. 2005. Efficacy of the combination rifampicinstreptomycin in preventing growth of Mycobacterium ulcerans in early lesions of Buruli ulcer in human. Antimicrob Agents Chemother. 49(8): 3182-6.

Etuaful, S., B. Carbonnelle., J. Grosset., S. Lucas and C.Horsfield. 2005. Efficacy of the combination rifampinstreptomycin in preventing growth of Mycobacterium ulcerans in early lesions of Buruli ulcer in humans. Ant Ag Chem. 49: 3182-6.

Feklistov A, Mekler V., Jiang Q., Westblade LF., Irschik H., Jansen R., Mustaev A., Darst SA and Ebright RH. 2008. Rifamycin do not function by allosteric modulation of binding of $\mathrm{Mg}^{2+}$ to the RNA polymerase active center, Proc Natl Acad Sci U S A. 105 (39):1482014825

Gomez A., Mve-Obiang V., Vray B., Rudnicka W., Shamputa IC., Portaels F., Meyers WM., Fonteyne PA., Realini
L. 2001. Detection of phospholipase C in non tuberculous mycobacteria and its possible role in hemolytic activity. $J$. Clin Microbiol. 39 (4):1396-401.

Guillot, J.F. 1989. Apparition et évolution de la résistance bactérienne aux antibiotiques. Annales de Recherches Vétérinaires, INRA Editions. 20 (1): 316.

Marsollier L., Aubry J., Saint André J.P., Robert R., Legras P., Manceau A.L., Bourdon S., Audrain C., and Carbonnelle B. 2003. Ecology and transmission of Mycobacterium ulcerans. Pathol Biol 51: 490-5.

Marsollier L., Honoré N., Legras P., Manceau A. L., Kouakou H., Carbonnelle B \& Cole S T. 2003. Isolation of three Mycobacterium ulcerans strains resistant to Rifampin after experimental chemotherapy in mice. Ant Ag. 47: 1228-1232.

Portaels F., Traoré H., De Ridder K \& Meyers W M. 1998. In vitro susceptibillity of Mycobacterium ulcerans to Clarithomycin. Ant Lag and Chem. 42: 2070-2073.

Stinear T.P., Mve-Obiang A., Small P.L., Frigui W., Pryor M.J., Brosch R., Jenkin G.A., Johnson P.D., Davies J.K., Lee R.E., Adusumilli S., Garnier T., Haydock S.F., Leadlay P.F., and Cole S.T. 2004. Giant plasmid-encoded polyketide synthases produce the macrolide toxin of Mycobacterium ulcerans. Proc Natl Acad Sci. 101:1345-1349.

\section{How to cite this article:}

Bakary Coulibaly, David N'golo Coulibaly, Clément Kouassi Kouassi, Ibrahim Konaté, Elise Solange Ngazoa-Kakou and Mireille Dosso. 2019. Molecular Investigation of Rifampicin Resistance in Clinical Isolates of Mycobacterium ulcerans in Côte D'ivoire. Int.J.Curr.Microbiol.App.Sci. 8(04): 913-919. doi: https://doi.org/10.20546/ijcmas.2019.804.105 